\title{
Pengalaman Perawat dalam Menghadapi Masa Persiapan Pensiun di RS Bhayangkara Denpasar
}

\author{
Tri Astuti Wira Pratiwi ${ }^{1}$, Ni Komang Sukraandini ${ }^{2}$, Putu Gede Subhaktiyasa ${ }^{3}$ \\ ${ }^{1,2,3}$ Sekolah Tinggi Ilmu Kesehatan Wira Medika Bali \\ Email:pratiwitrie@gmail.com
}

Submitted :27/03/2020

Accepted: 11/04/2020

Published: 07/09/2020

\begin{abstract}
Retirement is a separation from employment whereby an employee opts to cease working due to age or disability. Retirement preparation is a set of plan for employees to adapt to some challenges for their retirement. This study aimed at analyzing nurses' experiences towards retirement preparation. To accomplish this goal, this study used a descriptive qualitative design which was descriptive phenomenological approach. This study was conducted in 2019 in Bhayangkara Hospital Denpasar. The sample of this study was 4 participants. The technique used was purposive sampling. The data were collected through in-depth interview and field notes. The obtained data were analyzing through colaizi method. The results of this study were 4 themes such as, 1. nurses' understanding towards retirement preparation, 2. nurses' feelings towards retirement preparation, 3. the challenges faced by nurses towards retirement preparation, 4. ways to cope with challenges of retirement preparation. Researcher expectations For nurses who will retire can improve the ability and service of nurses in dealing with problems experienced by clients.
\end{abstract}

Keywords : nurses experiences, retirement

\begin{abstract}
Abstrak
Pensiun merupakan proses pemisahan seseorang individu dari pekerjaannya karena batasan umur atau disability. Masa Persiapan pensiun merupakan rancangan untuk pegawai sebagai langkah adaptasi terhadap hambatan-hambatan yang terjadi setelah masa pensiun. Tujuan penelitian ini mengetahui pengalaman perawat dalam menghadapi masa persiapan pensiun. Desain yang digunakan dalam penelitian ini adalah penelitian kualitatif dengan pendekatan fenomenologi deskriptif. Penelitian dilakukan pada tahun 2019 di RS Bhayangkara Denpasar dengan jumlah sample 4 orang partisipan. Tehnik sampling menggunakan purposive sampling. Pengambilan data dilakukan dengan menggunakan wawancara mendalam, menggunakan catatan lapangan dan dilakukan analisis menggunakan metode colaizi. Penelitian ini menghasilkan 4 tema yaitu 1. pemahaman perawat tentang masa persiapan pensiun (MPP), 2. perasaan perawat menghadapi persiapan pensiun (MPP), 3. hambatan perawat menghadapi masa persiapan pensiun (MPP), 4. cara mengatasi hambatan masa persiapan pensiun (MPP). Harapan peneliti Bagi perawat yang akan pensiun dapat meningkatkan kemampuan dan pelayanan perawat dalam menghadapi masalah yang di alami klien.
\end{abstract}

Kata kunci : pengalaman perawat, pensiun

\section{PENDAHULUAN}

Rumah sakit adalah suatu organisasi yang dilakukan oleh tenaga medis professional yang terorganisir baik dari prasarana kedokteran yang permanen, pelayanan kedokteran, asuhankeperawatan yang berkesinambungan, diagnosis serta pengobatan penyakit yang diderita oleh pasien (Ode, 2012). Rumah sakit harus berupaya meningkatkan kualitas jasa pelayanannya secara terus menerus. Semakin tinggi tingkat pemahaman masyarakat terhadap pentingnya kesehatan untuk mempertahankan kualitas hidup maka masyarakat pengguna akan semakin kritis dalam menerima produk jasa (Gunawan and Djati, 2011). Salah satu fasilitas pelayanan kesehatan memiliki 
peran yang sangat strategis dalam upaya mempercepat peningkatan derajat kesehatan masyarakat Indonesia. Salah satu profesi yang mempunyai peran penting di rumah sakit adalah tenaga perawat (Nurcahyadi, Dyah and Yanti, 2016)

Tenaga perawat adalah salah satu sumber daya manusia di rumah sakit yang berperan penting dalam penyelenggaraan upaya menjaga mutu pelayanan kesehatan di rumah sakit. Tenaga keperawatan bekerja selama 24 jam mendampingi dan memonitor kesehatan pasien secara terus menerus dan berkesinambungan untuk memberikan asuhan keperawatan yang komprehensif dan professional (Nurcahyadi, Dyah and Yanti, 2016). Tugas dan tanggung jawab perawat bukan hal yang ringan untuk dipikul. Perawat bertanggung jawab terhadap tugas fisik, administratif dari instansi tempat ia bekerja, menghadapi kecemasan, keluhan, dan mekanisme pertahanan diri pasien yang muncul pada pasien akibat sakitnya, ketegangan, kejenuhan dalam menghadapai pasien dengan kondisi yang menderita sakit kritis atau keadaan terminal, disisi lain ia harus di tuntut selalu tampil sebagai profil perawat yang baik oleh pasiennya (Nurcahyadi, Dyah and Yanti, 2016)

Perawat bekerja dalam kurun waktu tertentu, perawat akan menghadapi masa pensiun ketika menginjak usia madya. Perawat perlu mempersiapkan diri, baik fisik, psikis dan sosial agar dapat menghadapi masa - masa pensiun. Masa pensiun merupakan memasuki usia renta, fisik semakin melemah dan menua, makin banyak penyakit, semakin cepat lupa penampilan tidak menarik lagi, masa yang rumit, kegiatan kerja rutin tidak ada lagi, penghasilan dan kondisi kesehatan menjadi menurun dan hilangnya wewenang bahkan power (Hermi, 2016). Pada kenyataannya masa pensiun tidak datang secara tiba tiba, melainkan secara bertahap. Tahap pertama yang akan dilalui adalah tahap pra pensiun atau masa persiapan pensiun. Beberapa perusahaan ataupun instansi pemerintah memanfaatkan masa ini dengan serangkaian kegiatan atau yang bisa dikenal dengan program masa persiapan pensiun, Hakim 2007 (Fardila, Rahmi and Putra, 2017).

Berdasarkan Depkes RI (2014) bahwa PNS diberhentikan dengan hormat karena mencapai BUP yaitu, 58 (lima puluh delapan) tahun bagi Pejabat Adminstrasi, 60 (enam puluh) tahun bagi pejabat dan pimpinan tinggi dan sesuai dengan ketentuan peraturan perundang undangan bagi pejabat fungsional secara formal pegawai yang bekerja pada instansi pemerintah sepeerti pegawai negeri sipil maupun lembaga BUMN/BUMD akan menjalani masa pensiun setelah mencapai usia 56 tahun (PP No 32 tahun 1979). Menurut BKN (2015) Jumlah PNS Di Indonesia pada tahun 2015 adalah 4,7 juta orang dan dipensiunkan setiap tahunnya sebanyak 112.000 orang. Salah satu Rumah Sakit Negeri di Bali yaitu RS Bhayangkara Denpasar terdapat 132 perawat dan 13 perawat yang akan pensiun pada tahun 2019 - 2024.

Peneliti melakukan wawancara dengan perawat yang menghadapi masa persiapan pensiun pada tanggal 31 Juli 2019, partisipan 1 mengungkapkan kesulitan akan membiasakan diri dari bekerja di setiap hari dan yang nantinya hanya diam dirumah, tanggungan anak masih sekolah SMA dan kuliah semester pertengahan kita tidak tahu cukup apa tidak untuk kebutuhan hidup. Partisipan 2 mengungkapkan bingung mengambil kesibukan jika perawat pensiun, pensiun hidup di kota akan susah di sisi ekonomi jika balik ke kampung halaman ragu karena anak juga masih ada yang sekolah.Pada umumnya usia pensiun di Indonesia berkisar antara 55 tahun dimana seseorang berada pada tahapan dewasa menengah (middle adulthood). Pada masa dewasa 
menengah ini masih dapat dikatakan cukup produktif (Eliana, 2003)

Menurut penelitian yang dilakukan berjudul Kooping Perawat Usia Madya (5055) tahun Menghadapi Pensiun di RSUD Kabupaten Sukoharjo menyebutkan bahwa Seseorang mulai mencapai prestasi baik karir, pendidikan dan hubungan interpersonal walaupun kekuatan fisik maupun kekuatan mental menurun. Sebagai orang tua mereka harus bertanggung jawab dalam membesarkan anak - anak yang mulai beranjak remaja dan bahkan yang sudah berkeluarga. Perawat mengalami kehilangan financial, kehilangan status, kehilangan pekerjaan atau rutinitas saat memasuki pensiun. Orang yangmendekati masa pensiun, pensiun maupun pasca masa pensiun banyak mengalami Post Power Syndrome di karenakan dulunya ia memegang jabatan, memimpin, berpenghasilan dan di hormati (Oktavianus, 2011). Penelitian deskriptif kualitatif memberi gambaran / deskripsi terhadap fenomena yang diteliti dari partisipan, memahami dan menghasilkan teori (Afiyanty and Rachmawati, 2014). Pengalaman adalah pengetahuan hasil dari observasi pada suatu objek atau kejadian yang merupakan proses aktif dari pengamatan dan perubahan guna memahami situasi nyata (Syahdrajat, 2015).

Berdasarkan uraian diatas maka peneliti tertarik untuk melakukan penelitian "Pengalaman Perawat Dalam Menghadapi Masa Persiapan Pensiun di RS Bhayangkara Denpasar".

\section{METODE PENELITIAN}

Metode penelitian ini adalah penelitian kualitatif dengan pendekatan fenomenologi deskriptif, dengan focus penelitian adalah perawat dalam menghadapi masa Persiapan pensiun. Empat partisipan dipilih berdasarkan metode purposive sampling dengan kriteria
Perawat yang menghadapi masa persiapan pensiun, perawat mampu berkomunikasi secara kooperatif dalam mengungkapkan pengalamannya, perawat yang bersedia menjadi partisipan. Pengumpulan data dalam penelitian ini adalah wawancara mendalam (in depth interview) dan cacatan lapangan (field note). Pada penelitian ini semua partisipan sudah mendapatkan penjelasan terlebih dahulu tentang penelitian, prosedur penelitian dan hak hak partisipan dengan menandatangani informed consent. Analisa data dilakuka dengan Collaizi 7 step proses.

\section{HASIL DAN PEMBAHASAN \\ 1.Pemahaman Perawat Tentang Masa Persiapan Pensiun (MPP)}

Partisipan menggambarkan pemahaman tentang masa persiapan pensiun adalah masa mempersiapkan diri yang sudah mendekati purna tugas, Batas Usia Pensiun (BUP) dan Pembekalan Masa Persiapan Pensiun (MPP).

a. Masa persiapan diri

Partisipan menjelaskan masa persiapan diri menjelang masa pensiun dapat di gambarkan dalam satu transkrip adalah sebagai berikut :

"MPP itu waktu yang di berikan kepada pegawai negeri sipil selama Satu tahun dengan tujuan memberikan kesempatan kepada setiap pns untuk mempersiapkan diri menjelang masa pensiun."

$$
\text { (P1.L3-8) }
$$

b. Batas Usia Pensiun (BUP)

Partisipan menjelaskan Batas Usia Pesiun (BUP) perawat Polri yaitu 58 tahun dapat di gambarkan dalam dua transkrip adalah sebagai berikut :

Untuk perawat polri batas usia pensiun itu 58 tahun jika seseorang memiliki keahlian lebih akan pesiunkan 60 tahun

"Masa persiapan pensiun itu masa dimana akan mamasuki fase pensiun, 
kita tidak bisa mengatakan tidak mau karena umur tidak bisa berbohong 58 tahun itu batas usia pensiun kalau PNS perawat Polisi. sebelum pensiun terdapat MPP yaitu masa persiapan pensiun kita 1 tahun sebelum pensiun mendapat pembekalan bisa di ambil dan tidak, jika di ambil kita di bebas tugaskan dari tugas keseharian." (P4.L3-12)

\section{c. Pembekalan Masa Persiapan Pensiun}

Partisipan menjelaskan pembekalan masa persiapan pensiun (MPP) yaitu dilakukan pelatihan keterampilan yang diminati seperti mitra waralaba dan kewirausahaan dapat di gambarkan dalam dua transkrip adalah sebagai berikut :

"Pembekalan dan pelatihan mitra waralaba, mitra wara laba itu seperti membeli brand yang sudah punya nama kayak indomaret, C'BEZT, ya tapi modal yang cukup sesuai kantong kita ada juga pengolahan jamur tiram dijaman sekarang ini kan lumayan peminat jamur seperti itu salah satunya." (P2.L24-28)

"Pembekalan seperti pelatihan keterampilan kewirausahaan, contoh berkebun, beternak, berdagang. Berkebun itu seperti menanam buah sayuran yang berkhasiat contoh jeruk nipis kan gampang hidupnya manfaatnya kaya vit $C$, bisa menghilangkan gatal di tenggorokan, kalau berternak ya usaha ayam kampung telur bisa jual dagingnya juga”

(P4.L21-30)

\section{Perasaan perawat memasuki Masa Persiapan Pensiun}

Saat memasuki Masa Persiapan Pensiun (MPP) yaitu partisipan mengungkapkan perasaan senang, sedih, cemas dan tenang dapat di gambarkan dalam lima transkrip adalah sebagai berikut :

"Kalau senangnya, di umur sekarang ini beban tugas sedikit berkurang biasanya beban kerja kan lumayan pasien gak bisa bilang stop tidak jaga malam lagi hanya pagi saja, (P1.L27-31)

" kalau sedihnya ya kita gak bisa bohong juga ekonomi pasti berkurang apalagi anak - anak masih biaya sekolah, belum buat kebutuhan di rumah, belum menyama braya di desa pasti itu kita pikirkan."

\section{Hambatan Perawat Memasuki Masa Persiapan Pensiun}

Partisipan menggambarkan hambatannya dalam memasuki masa persiapan pensiun yaitu masalah ekonomi, akan kehilangan teman, serta akan kebingungan untuk menentukan kegiatan setelah pensiun dapat di gambarkan dalam 3 transkrip adalah sebagai berikut :

"yang pertama pasti ekonomi itu sangat penting kalau ekonomi bermasalah pasti di hubungan keluarga itu kacau dik, yang kedua kita hampir 38 tahun bekerja setiap hari ke RS sekarang bayangkan kita di rumah aja pasti bosan biasa kita ketemu dengan teman sejawat, sharing masalah kerjaan itu sulit saya juga bingung pensiun saya mau ngambil kesibukan apa peminatan saya belum pikirkan."

(P1.L46-50)

"Hambatan saya, umur saya sudah mau pensiun tetapi saya masih memiliki anak yang sekolah cukup banyak mengeluarkan biaya pastinya karena anak saya mau kuliah uang pangkal kuliah utamanya saya juga bingung mengambil kesibukan apa jika pensiun harus di pikirkan jangka panjangnya tidak bisa langsung mengambil keputusan." 
(P1.L49-55)

\section{Cara Mengatasi Hambatan Masa Persiapan Pensiun}

Partisipan menggambarkan cara mengatasi hambatan dalam menghadapi masa persiapan pensiun yaitu dengan mengikuti seminar agar menambah wawasan, yoga menenangkan diri dan membuka usaha setelah pensiun agar mendapat pemasukan nantinya dapat di gambarkan dalam empat transkrip adalah sebagai berikut :

mengikuti sosialisasi atau seminar untuk menambah skill saya rencana saya mau home care perawatan DM, biar saya pensiun masih bisa ilmu di ruangan juga terpakai dimasyarakatbercocok tanaman obat"

$$
\text { (P1.L52-57) }
$$

"Mungkin saya memodalkan istri saya jualan dan saya membantunya jualan setelah pensiun nanti saya juga belajar bertenak karena saya punya tanah sedikit di kampung untuk berternak."

(P2.L57-60)

\section{Pembahasan \\ 1)Pemahaman Perawat Tentang Masa Persiapan Pensiun}

Berdasarkan hasil temuan dalam penelitian ini, keempat partisipan di RS Bhayangkara Denpasar telah memaparkan dengan baik akan pemahaman mereka terhadap masa persiapan pensiun. Pemahaman partisipan 1 terhadap masa persiapan pensiun dimaknai sebagai masa persiapan diri. Pernyataan partisipan 1 yang telah dideskripsikan sebelumnya menunjukkan bahwa partisipan memahami masa persiapan pensiun dilakukan selama satu tahun untuk mempersiapkan diri partisipan 1 menjelang masa pensiunnya. Sejalan dengan ini, pemahaman partisipan 2 dan partisipan 4 akan masa persiapan pensiun ini ditilik dari Batas Usia Pensiun (BUP) perawat polri. Berdasarkan pernyataan-pernyataan kedua partisipan menunjukkan pemahaman yang baik akan masa persiapan pensiun. Pemahaman yang baik akan masa persiapan pensiun di RS Bhayangkara Denpasar juga ditunjukkan dari pernyataan-pernyataan partisipan 2 dan 4 yang menjelaskan tentang pemberian pembekalan MPP dalam bentuk pelatihan mitra waralaba serta keterampilan kewirausahaan.

Berdasarkan hasil penelitian mengenai pemahaman masa persiapan pensiun yang di ungkapkan oleh semua partisipan, dapat disimpulkan bahwa seluruh partisipan menunjukkan pemahaman yang baik dan menunjukkan sikap menerima. Pemahaman serta persiapan diri (retirement preparation) yang dilakukan ialah mengikuti pelatihanpelatihan yang telah disediakan di RS Bhayangkara Denpasar. Hal ini sejalan dengan konsep yang dikemukakan oleh (Kim, Kwon and Anderson, 2005), serta konsep kesiapan yang dikemukakan (Shonhadji, 2012), yaitu kesiapan (readiness) adalah penanda kognitif terhadap perilaku dari penolakan atau dukungan terhadap upaya perubahan dan titik kedewasaan yang berupa kesiagaan, kesiapan, kematangan untuk dapat menerima dan memperaktekan tingkah-laku tertentu. Partisipan sudah mampu memaknai dan memiliki kesiapan (readiness) atau penanda kognitif sebagai upaya perubahan kehidupan dan titik kedewasaan yang berupa kematangan untuk dapat menerima dan mempersiapakan halhal untuk cukup melakukan sesuatu setelah pensiun.

\section{2) Perasaan Perawat Memasuki Masa Persiapan Pensiun}

Perasaan yang dialami partisipan saat memasuki masa persiapan pensiun (MPP) berbeda-beda. Berdasarkan hasil observasi dan wawancara, partisipan 1 mengungkapkan perasaan senang dan sedih. Perasaan senang muncul karena partisipan 1 
di usianya yang berumur 58 tahun dapat merasakan keringanan beban tugas. Namun, partisipan juga merasakan kesedihan karena berkurangnya pendapatan untuk menunjang biaya sekolah, kebutuhan rumah, serta keperluan bermasyarakat. Partisipan 2 dan Partisipan 3 menunjukkan perasaan yang sama berupa perasaan cemas. Kedua partisipan menghadapi kecemasan dalam hal finansial untuk menghidupi kebutuhan keluarga. Partisipan 3 juga menambahkan perasaan bingung karena belum mempersiapkan serta mempertimbangkan kegiatan yang akan dilakukan nanti setelah pensiun nantinya. Disisi lain, partisipan 4 merasakan perasaan tenang dan senang dalam menghadapi masa pensiunnya.

Perubahan faktor psikologis yang dirasakan seluruh partisipan sejalan dengan teori yang dikemukakan menjelaskan bahwa masa transisi menuju pensiun akan menimbulkan perubahan psikis yaitu salah satunya kecemasan (Nurcahyadi, Dyah and Yanti, 2016). Namun, seluruh partisipan tidak menunjukkan sikap negatif hingga menolak melakukan program persiapan pensiun. Faktor-faktor yang mempengaruhi kecemasan yang dialami partisipan 1,2 , dan 3 dipengaruhi oleh berkurangnya pendapatan yang berkaitan erat dengan jumlah keluarga yang ditanggung. Sedangkan, partisipan 4 merupakan partisipan yang memiliki tingkat emosi stabil dan tenang karena tingkat keluarga yang ditanggung tidak ada dan memiliki persiapan yang matang sebelum memasuki masa pensiun. Hal ini selaras dengan teori yang dikemukakan (Hakim, 2007), bahwa dalam menghadapi masa pensiun, pegawai akan terbebas dari rasa cemas apabila sudah melakukan persiapan yang matang.

\section{3) Hambatan Perawat Dalam Memasuki Masa Persiapan Pensiun}

Berdasarkan hasil observasi dan wawancara, 3 partisipan menghadapi hambatan dalam memasuki masa persiapan pensiun. Partisipan 1 dan 2 mengalami hambatan yang serupa yaitu menekankan pada hambatan ekonomi, akan kehilangan teman, serta akan kebingungan untuk menentukan kegiatan setelah pensiun.. Partisipan 3 menekankan pada kesulitan finansial karena pemasukan akan berkurang serta tanggungan anak untuk sekolah belum terselesaikan. Hanya partisipan 4 yang tidak mengalami atau merasakan hambatanhambatan dalam memasuki masa persiapan pensiun.

Hambatan-hambatan ini sejalan dengan perubahan psikososial yang dikemukakan (Muhith and Siyoto, 2016). Partisipan 1, 2, dan 3 mengalami perubahan nilai yang dikaitkan dengan produktivitas mereka akan mengalami pensiun serta perubahan yang dialami yaitu nilai seseorang diukur oleh produktivitasnya dan identitas yang dikaitkan dengan peranan dalam pekerjaan, bila seorang pensiun (purna tugas) maka ia akan mengalami kehilangan financial / income berkurang, kehilangan status (memiliki jabatan / posisi yang ukup tinggi lengkap dengan segala fasilitasnya), kehilangan teman / rekan kerja, kehilangan kegiatan pekerjaan.

\section{4) Cara Mengatasi Hambatan Masa Persiapan Pensiun}

Hambatan-hambatan yang disadari oleh partisipan diatasi dengan upaya-upaya. Berdasarkan uraian yang disampaikan oleh seluruh partisipan, partisipan 1 mengatasi hambatan yang dilakukan dengan mengikuti sosialisasi atau seminar guna menambah skill serta dapat digunakan dalam bermasyarakat seperti melakukan kegiatan bercocok tanam. Berbeda dengan partisipan 1, partisipan 2 menghadapi ketidakpastian dimasa mendatang dengan mengembangkan dana yang dimiliki bersama istri untuk melakukan bisnis bersama serta belajar beternak untuk kegiatan penunjang sehari-hari. Partisipan 3 mengatasi hambatan yang dirasakan dengan melakukan kegiatan seperti yoga. Kegiatan 
ini dipandang mampu menghilangkan rasa stress serta kecemasan setelah mengalami pensiun. Dan partisipan 4 sudah memiliki bekal saat ia akan pensiun nantinya yaitu saat ini partisipan sudah membuka usaha menyewakan lapangan futsal.

Upaya-upaya atau koping yang dilakukan partisipan 1,2,3,4 sejalan dengan teori yang mengungkapkan tentang kegiatan-kegiatan yang dilakukan pegawai setelah pensiun yang merupakan bentuk upaya kognitif dan behavior guna memenuhi tuntutan-tuntutan internal dan eksternal Upaya-upaya yang dilakukan tersebut merupakan upaya mempersiapkan kesejahteraan sosial setelah menghadapi masa pensiun (Eliana, 2003). mendefinisikan kesejahteraan sosial merupakan suatu keadaan atau kondisi kehidupan manusia yang tercipta ketika berbagai permasalahan sosial dapat dikelola dengan baik, ketika kebutuhan manusia dapat terpenuhi dan ketika kesempatan sosial dapat dimaksimalkan. Memasuki pekerjaan sektor informal menjadi pembuktian bahwa mereka dapat menggunakan kesempatan sosial secara maksimal dan kebutuhannya dapat terpenuhi sehingga permasalahan sosial dan ekonomi dapat diselesaikan.

Bagi kebutuhan pensiun yang wajib dipenuhi, mereka harus mempertahankan ekonomi kesejahteraan dan kesejahteran sosialnua agar mampu menuju kesejahteraan diri dan keluarganya. Sifat kebutuhan semakin hari bukan semakin menurun, melainkan semakin meningkat. Peningkatan kesejahteraan individu maupun keluarga berhak dilakukan oleh siapa pun dengan cara yang berbeda di setiap usaha yang dilakukan. Jadi usaha-usaha yang dilakukan setelah pensiun dapat merupakan perwujudan untuk upaya mencapai kesejahteraan sosial.Mengingat pentingnya mempersiapkan pensiun, sebagian besar kantor/instansi juga memperhatikan perencanaan pensiun pegawainya dengan melaksanakan program persiapan pensiun. Oleh karena itu, sangat penting bagi divisi pengembangan SDM memperhatikan kesejahteraan pegawainya, baik pada saat masih bekerja maupun pada saat telah pensiun. Dengan adanya program persiapan pensiun bagi para pegawai, akan sangat membantu pegawai untuk dapat menghadapi masa pensiun. Dalam penelitian ini, RS Bhayangkara Denpasar juga telah menjalankan program pensiun terhadap kesiapan pensiun partisipan.

\section{SIMPULAN}

Berdasarkan hasil penelitian yang telah dilakukan didapatkan fenomenologi pengalaman perawat dalam menghadapi masa persiapan pensiun di RS Bhayangkara Denpasar yaitu pemahaman perawat tentang masa persiapan pensiun (MPP) dengan sub tema yaitu masa persiapan diri, batas usia pensiun (BUP), pembekalan MPP. Perasaan perawat memasuki masa persiapan pensiun (MPP) dengan sub tema yaitu perasaan senang, sedih, cemas dan tenang. Hambatan perawat dalam menghadapi masa persiapan pensiun (MPP) dengan sub tema yaitu masalah ekonomi akan kehilangan teman, serta akan kebingungan untuk menentukan kegiatan setelah pensiun. Cara mengatasi hambatan masa persiapan pensiun (MPP) dengan sub tema yaitu dengan cara mengikuti seminar, mengikuti yoga dan membuka usaha.

Disarankan bagi perawat yang akan pensiun dapat meningkatkan kemampuan dan pelayanan perawat dalam menghadapi masalah yang di alami klien. Peneliti Selanjutnya diharapkan dapat digunakan sebagai dasar atau referensi bagi peneliti selanjutnya yang ingin mengembangkan penelitan ini lebih lanjut serta studi komparasi bagi peneliti atau mahasiswa yang tertarik dalam penelitian pengalaman perawat dalam menghadapi masa persiapan pensiun. 
DAFTAR PUSTAKA

Afiyanty and Rachmawati .2014. Metode Penelitian Kualitatif Dalam Riset Keperawatan. jakarta: PT Raja Grafindo.

BKN. 2015. SK Pensiun Pensiun Pegawai Negeri 2015. Jakarta : Badan Kepegawaian Nasional. Diunduh dari : https://www.bkn.go.id

Depkes, R.I. 2014. Batas usia pensiun (BUP). www.depkes.go.id diakses tanggal 2Februari 2014

Dinkes, Provinsi bali. 2018. Laporan Jumlah perawat di bali.Denpasar

Eliana, R. 2003. 'Konsep diri pensiunan', Sumatra Utara: USU digital library, 2, pp. 158-162.

Fardila, N., Rahmi, T. and Putra, Y. 2017 ' $=0.413$, thus conclude there is a significant relationship between family social support with retirement readiness on civil servants. Key Word: Perception, family social support, retirement readiness, civil servants', pp. 1-11.

Gunawan, K. and Djati, S. P. 2011. 'Kualitas Layanan dan Loyalitas Pasien (Studi pada Rumah Sakit Umum Swasta di Kota SingarajaBali)', Jurnal Manajemen dan Kewirausahaan, 13(1). doi: 10.9744/jmk.13.1.32-39.

Hakim, S. N. 2007. 'Perencanaan dan persiapan menghadapi masa pensiun'.

Hermi. 2016. Kerja Bahagia Pensiun Mulia. jakarta: Mitrawacana Media.

Kim, J., Kwon, J. and Anderson, E. A. 2005. 'Factors related to retirement confidence: Retirement preparation and workplace financial education', Financial Counseling and Planning. Association for Financial Counseling and Planning Education, 16(2), pp. 77-89.
Muhith, A. and Siyoto, S. 2016. Pendidikan Keperawatan Gerontik. yogyakarta: Andi Offset.

Nurcahyadi, E., Dyah, W. and Yanti, R. 2016. 'Hubungan tingkat stres kerja dengan kinerja perawat', 4(2), pp. 2235 .

Ode .2012. Konsep Keperawatan. yogyakarta: Nuha Medika.

Oktavianus .2011. 'Koping Perawat Usia Madya ( 50-55 Tahun ) Menghadapi Pensiun Di RSUD Kabupaten Sukoharjo', pp. 17-26.

Shonhadji, N. 2012 'Factors of Auditor's Readiness in Implementing IFRS in Indonesia', Journal of Economics, Business, and Accountancy Ventura, 15(1), pp. 133-144.

Syahdrajat. 2015. Panduan Menulis Kedokteran dan Kesehatan. jakarta: Prenada Media Group. 